\title{
WAHANA DUNIA PERMAINAN TRADISIONAL DAN MODERN
}

\author{
Pretty Angel Duxanda ${ }^{1)}$, Dewi Ratnaningrum ${ }^{2)}$ \\ 1) Program Studi S1 Arsitektur, Fakultas Teknik, Universitas Tarumanagara, Pretty_08_angel@yahoo.com \\ ${ }^{1)}$ Program Studi S1 Arsitektur, Fakultas Teknik, Universitas Tarumanagara, dewir@ft.untar.ac.id
}

\begin{abstract}
Abstrak
Kota Jakarta merupakan kota Metropolis. Pada suatu kota pentingnya adanya suatu tempat wisata yang dimana dapat berfungsi untuk menghibur masyarakat untuk menghilangkan kepenatan, meningkatkan daya tarik suatu kota dan juga menjadi sumber ekonomi bagi masyarakat sekitar. Wisata rekreasi merupakan salah satu jenis wisata yang cocok di kota Jakarta, karena wisata rekreasi merupakan tempat wisata yang dimana pengunjung yang datang mengikuti aktivitas program didalamnya. Program yang diangkat pada wisata ini berupa kegiatan yang sering dilakukan orang-orang yaitu game/permainan. Permainan yang disediakan adalah permainan tradisional dan modern yang dimana supaya permainan tradisional kembali dikenal dan permainan modernpun juga tetap berkembang dan bisa dinikmati semua kalangan. Konsep perancangan adalah transformasi yang dimana dari program disusun mulai dari permainan tradisional ke modern dan juga pada pengunanaan material dan pada tiap zona pun berbeda. Zona terbagi menjadi dua yaitu zona permainan tradisional dan zona permainan modern.
\end{abstract}

Kata kunci: Metropolis, Permainan Modern, Permainan Tradisional, Wisata Rekreasi

\begin{abstract}
The city of Jakarta is the city of Metropolis. In a city the importance of a tourist place which can serve to entertain the community to eliminate fatigue, increase the attractiveness of a city and also become an economic resource for the surrounding community. Recreational tourism is one type of tourism that is suitable in the city of Jakarta, because recreational tourism is a tourist place where visitors come to participate in program activities in it. The program raised in this tour is in the form of activities that people often do is playing games. The games provided are traditional and modern games where traditional games are known again and modern games are still developing and can be enjoyed by all groups. The design concept is a transformation in which programs are arranged from traditional to modern games and also on material administration and in each zone is different. The zone is divided into two, the traditional game zone and the modern game zone.
\end{abstract}

Keywords: Metropolis, Modern Game, Recreational tourism, Traditional game

\section{PENDAHULUAN}

\section{Latar Belakang}

Kota Jakarta merupakan kota metropolis. Yang di mana kota metropolis merupakan kota induk. Dan kota metropolis ditandai dengan jumlah kepadatan penduduk yang tinggi, aktivitas yang padat didalamnya, pergerakan yang cepat, dan prinsip kapitalisme yang kuat. Dan dalam kota metropolis memiliki karakter umum dalam hal ekonomi, politik, serta keberagaman sosial dan budaya. Dan pada kota Jakarta sudah mencakup dari semua tanda dan karakter dari kota metropolis.

Tourism atau yang dikenal dalam Bahasa Indonesia adalah pariwisata. Pariwisata adalah kegiatan yang dilakukan orang dengan pergi ke tempat wisata yang memiliki tujuan untuk bersenang-senang. Tempat wisata bisa menjadi salah satu tempat yang tepat untuk menenangkan diri dan menyegarkan pikiran dari kegiatan sehari-hari. Dalam pariwisata sangat dibutuhkan dalam suatu kota selain untuk tempat yang bersifat menghibur, bersantai, dan melakukan kehiatan menyenangkan diluar dari kegiatan sehari-hari, dapat menjadi tempat 
sumber ekonomi dan sebagai daya tarik untuk menarik penduduk dari luar kota dan luar negeri untuk berdatangan.

Dalam mengisi waktu luang orang-orang sering melakukan kegiatan bermain suatu permainan baik individu maupun kelompok. Permainan yang dimana dapat kita lihat selalu berkembang dari generasi ke generasi. Dan permainan pun pada jaman sekarang sudah memiliki tekhnologi yang tinggi dan semangkin lama permainan tradisional pun mulai terlupakan dan hilang. Padahal jika kita lihat permainan tradisional Indonesia meupakan salah satu bagian dari budaya Indonesia. Maka daripada itu pengenal akan permainan tradisional harus kembali dinaikkan dan perkembangan permainan modern harus tetap dikenalkan agar tetap menyeimbangkan dengan perkembangan permainan dari seluruh negara.

\section{Permasalahan}

Pada Kota Jakarta merupakan kota yang padat. Dari data yang didapatkan penduduk kota Jakarta selalu meningkat setiap tahunnya. Sehingga menimbulkan penduduk yang padat, dan memilki permasalah paling tinggi adalah kemacetan. Dan dari kemacetan dan kepadatan ini mempengaruhi kehidupan sehari-hari. Dari sini dapat terlihat aktivitas yang dilakukan masyarakat rata-rata lebih banyak diluar rumah. Dari aktivitas sehari-hari yang membuat jenuh, membuat orang mencari kegiatan yang menyenangkan untuk melepas kepenatan.

Tempat wisata merupakan salah satu tempat yang dimana sering dikunjungi orang untuk mencari kesenangan diluar aktivitas sehari-hari. Wisata rekreasi merupakan wisata yang lebih cocok pada kota Jakarta karena wisata rekreasi dimana orang ikut berinteraksi dan bermain pada program yang sudah disediakan. Tetapi tempat wisata rekreasi di kota Jakarta kurang. Salah satu tempat wisata bermain yang dimana isinya permainan sedikit adanya di kota Jakarta dan hanya bagian kecil dari suatu program tempat wisata lain saja. Padahal jika dilihat permainan merupakan kegiatan yang diminatin dari berbagai kalangan dan usia.

Permainan tradisional merupakan salah satu budaya Indonesia yang sekarang sudah mulai menghilang dan ini bisa menjadi peluang untuk menaikkan permainan tradisional dengan tempat wisata dan permainan modern yang terus berkembang. Oleh daripada itu timbullah berbagai permasalahan mulai dari masalah sosial, problem pemilihan tapak, problem kegiatan, problem desain dan perancangan yang mempengaruhi dalam proses perancangan.

\section{Tujuan}

Mampu menemukan dan menganalisis tempat wisata yang masih kurang di Kawasan kota Jakata. Mampu memaparkan kebutuhan dan jenis wisata dari tempat wisata tersebut. Mengusulkan program dan lokasi wisata yang mampu membangun, menghidupkan, melengkapi, dan menarik pengunjung sesuai dengan kebutuhan masyarakat, berdampak postif bagi Kawasan Jakarta khususnya lingkungan sekitar.

\section{METODE}

Perancangan dilakukan melalui metode kualitatif dengan teknik pengumpulan data dari studi literatur buku dan pencarian data melalui internet. Melakukan survei lapangan ke beberapa tempat wisata yang mengandung permainan dan ke lokasi tapak untuk mengetahui keadaan sekitar, program yang dibutuhkan, lokasi titik tapak yang layak digunakan, serta melakukan analisis terhadap tapak. Melakukan diskusi atau wawancara dengan pihak TMII untuk pemilihan tapak. Menyebarkan kuesioner untuk melihat ketertarikan masyarakat terhadap berbagai macam mulai dari kegiatan dan permainan dari tradisional hingga modern. Menganalisis data-data yang telah diperoleh untuk menghasilkan program ruang, zoning, dan konsep massa. 


\section{DISKUSI DAN HASIL}

Wahana dunia pemainan trasional dan modern ini terletak di dalam Taman Mini Indonesia Indah (TMII). TMII merupakan tempat wisata rekreasi di Jakarta yang bertemakan tentang kebudayaan tradisional Indonesia. Yang dimana tempat wisata ini berisikan berbagai macam rumah ada dari berbagai daerah. Tetapi tidak menutup kemungkinan untuk menemukan tempat wisata diluar dari kebudayaan Indonesia. Pada TMII juga terdapat berbagai macam wahana seperti kolam renang snowbay, dunia air tawar, dan lain-lain. Tetapi pada TMII wahana yang menawarkan tentang permainan belum tersedia baik permainan tradisional maupun modern. Maka dari pada itu pemilihan lokasi diletakkan di dalam TMII.

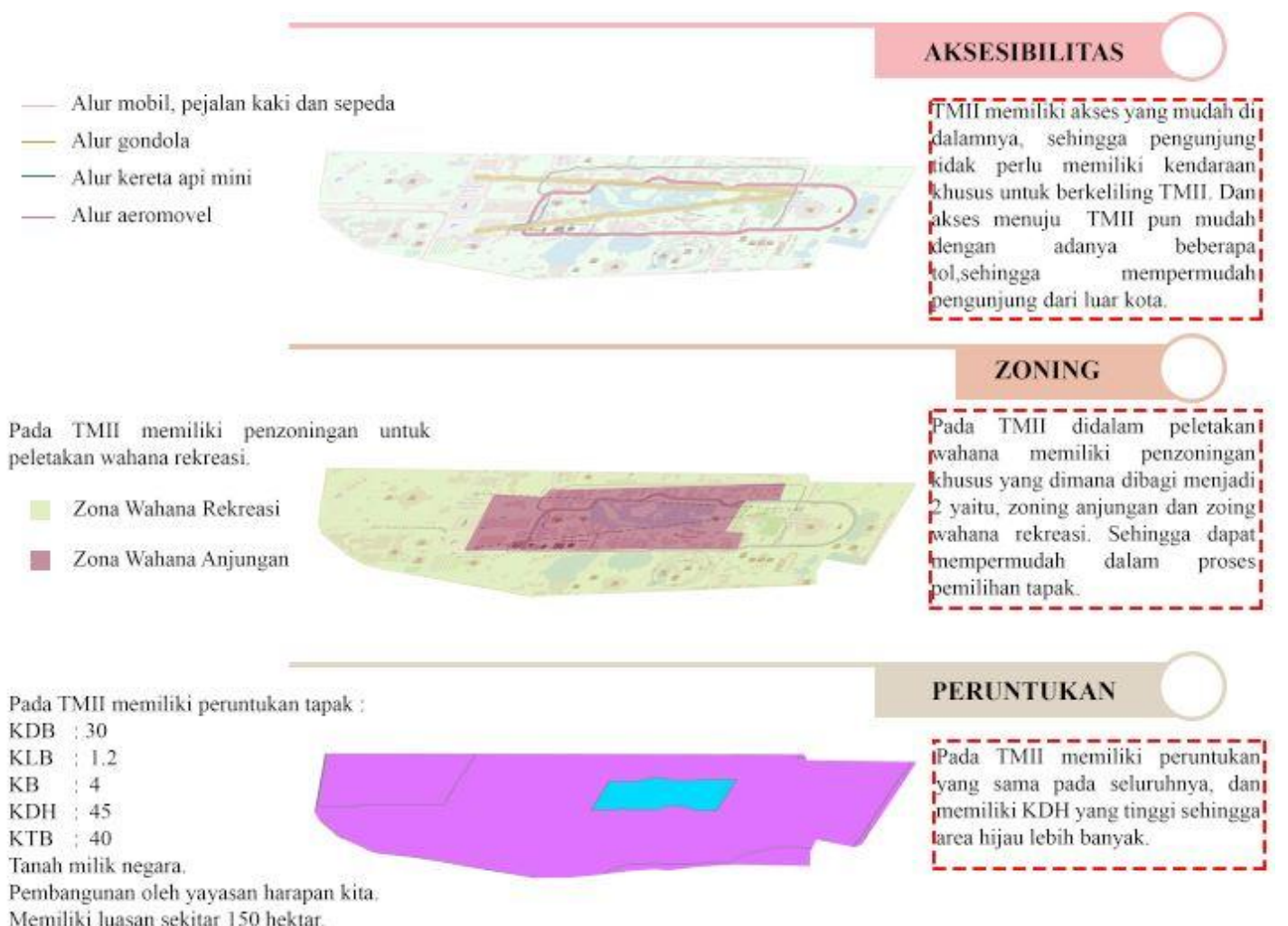

Gambar 1. Analisis Lingkungan

Sumber: Data Pribadi, 2019

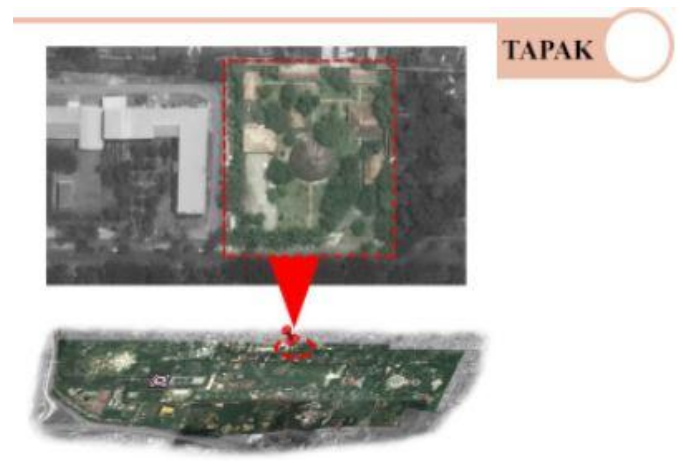

Gambar 2. Tapak

Sumber: Data Pribadi, 2019

Tapak merupakan area dari wahana desa seni. Pada tapak ini merupakan tempat diadakan acara pameran mainan tradisional maka daripada itu pemilihan tapak pada bagian ini supaya bisa mengembangkan menjadi tempat permainan tradisional yang permanen. 
Pada tapak terdapat taman kaktus, program taman kaktus tidak dihilangkan tetapi dijadikan bagian dari landscape penghubung antara wahana perencanaan dengan wahana taman optik hidup yang berada pada sebelah tapak.

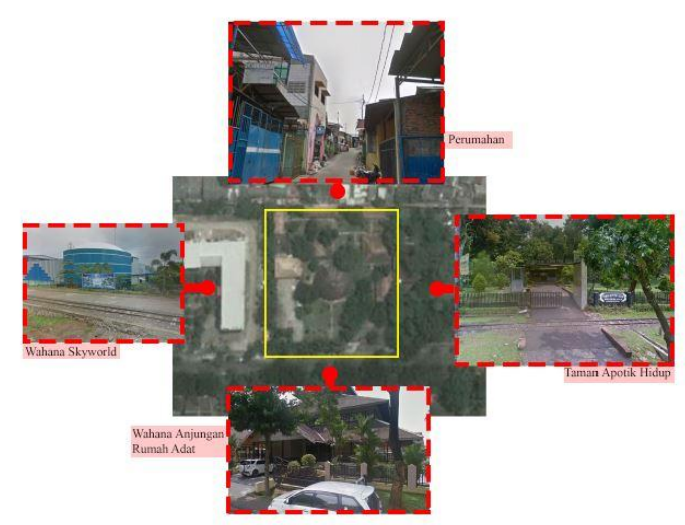

Gambar 3. Foto Sekitar Tapak

Sumber: Data Pribadi, 2019

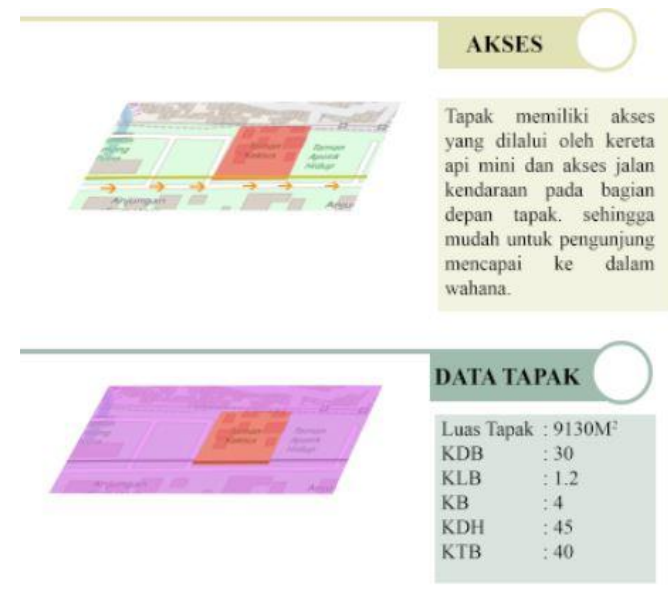

Gambar 4. Data Tapak

Sumber: Data Pribadi, 2019

Tapak dikelilingi oleh berbagai wahana rekreasi (Gambar 3). Akses pada tapak pun mudah dan sebagian besar bisa memakai akses yang sudah di sediakan TMII yaitu berupa bus, kereta mini, dan juga sepeda. Pada kendaraan pribadi dan bus rombongan telah disediakan parkiran khusus pada TMII yang berjarak $\pm 235 \mathrm{M}$ dari tapak.

Program yang disediakan berupa permainan tradisional dan permainan modern. Pada program permainan tradisional disediakan karena sudah kurangnya pengetahuan dan pengenalan masyarakat terutama generasi muda akan permainan tradisional. Padahal jika kita sadari permainan merupakan salah satu budaya Indonesia yang paling berharga. Dan kurangnya lahan permainan menyebabkan salah satu masalahnya.

Permainan tradisional yang disediakan merupakan permainan tradisional dari berbagai pulau (Gambar 5). Pada sebagian permainan tiap pulau sama akan tetapi bentuk mainan dan peraturan saja yang berbeda. Seperti contoh, bentuk gasing memiliki bentuk yang berbeda pada tiap daerah tetapi cara bermainnya sama.

Permainan modern merupakan permainan yang bermainan menggunakan mesin atau alat. Pada permainan modern dari generasi ke generasi terus berkembang dan berubah disebabkan oleh tekhnologi yang selalu berkembang. Pada permainan modern sampai saat ini sudah memiliki berbagai macam jenis (Tabel 1). 
Permainan modern yang disediakan pada program perancangan ini adalah arcade game, console game, dan VR game. Karena tiga permainan tersebut merupakan permianan cocok untuk ditempatkan di tempat wisata dan bisa dimainkan secara berkelompok atau sendiri. Dan perkembangan permainan modern di Indonesia pun semangkin berkembang dan banyaknya komunitas gamers yang bermunculan baik sehingga bisa menarik pengunjung dengan program kegiatan tambahan seperti kompetisi atau tournament.

Tabel 1. Jenis Alat Permainan

Nama Permainan
Arcade Games
Console Games
Handle Games
Mobile Games
VR Games

Sumber: Data Pribadi, 2019

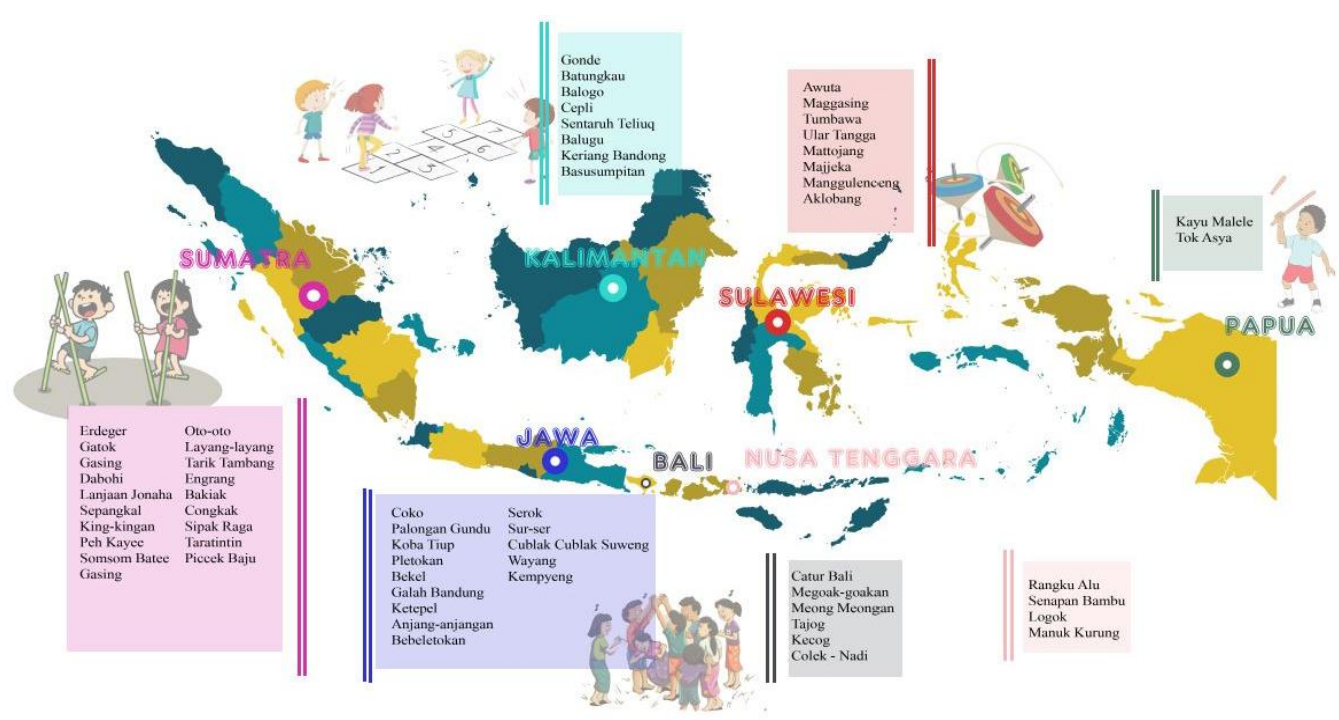

Gambar 5. Peta Permainan Tradisional Sumber: Data Pribadi, 2019

Konsep perancangan wahana ini diangkat dari gabungan antara permainan tradisional dan permainan modern, yaitu transformasi. Transformasil merupakan sebuah proses perubahan. Yang dimana program merupakan perubahan dari permainan tradisional hingga modern. dari permainan ini di jabarkan dan diambil beberapa nilai-nilai penting di dalamnya (Gambar 6). 


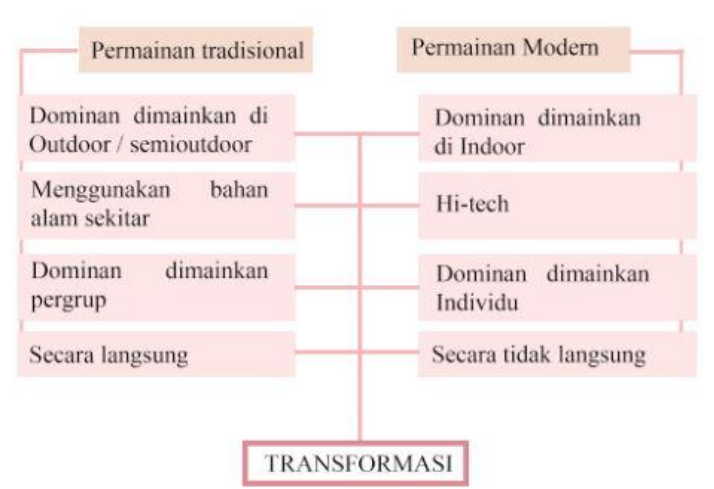

Gambar 6. Konsep

Sumber: Data Pribadi, 2019

Dari hasil penjabaran konsep ini menjadi suatu proses pembentukan gubahan massa (Gambar 7). Dan lalu di terapkan didalam proses pembentukan ruang yang dimana pada bagian tradisional karena permainan dominan dimainkan secara outdoor / semioutdoor sehingga ruangan dibuat terbuka tidak bersekat dan hanya di tutupi dengan fasad. Lalu memiliki nilai sosialisme yang tinggi sehingga pada pembetukan ruang didalam juga tidak bersekat. Dan dari material menggunakan material dan warna alam seperti kayu, bata, dan vegetasi. Karena permainan tradisional biasa dimainkan di alam dan menggunakan bahanbahan alam sekitar.

Pada bagian permaian modern dimainkan dominan secara indoor dan menggunakan alat sehingga dibuat didalam ruangan tertutup dan ruangan dibuat lebih bersekat karena permainan modern lebih melambangkan sifat yang individual. Penggunaan material lebih kearah modern dimana ruang banyak menggunakan LED sebagai ekstetiknya. Untuk bagian permainan modern lebih dominan menggunakan listrik dan banyak kabel sehingga menggunakan lantai raising floor sehingga pengunjung dapat bebas dari kabel. Dan juga lantai menggunakan lantai sensor dan lantai LED. (keterangan bentuk ruangan tradisional dan modern pada gambar 13).
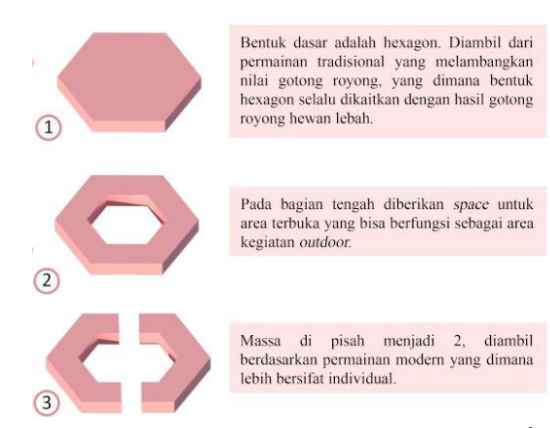

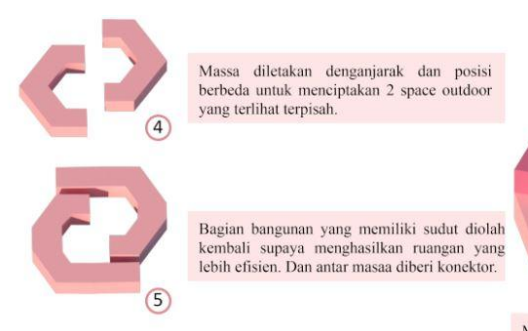

Gambar 7. Proses Gubahan Massa

Sumber: Data Pribadi, 2019

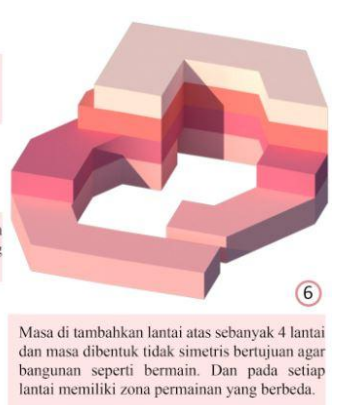

(6) bangunan seperti bermain. Dan pada setiap
lantai memiliki zona permainan yang berbeda.

redi, 2019
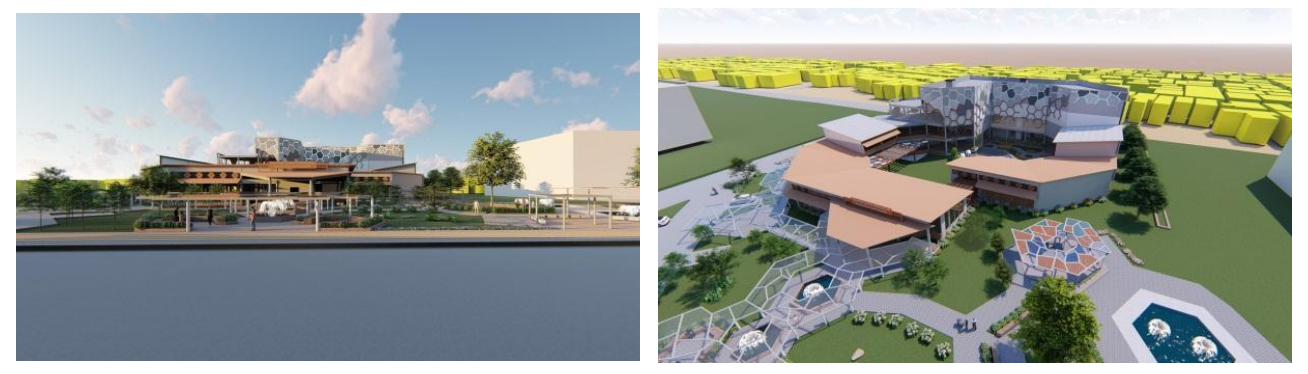

Gambar 8. Perspektif Eksterior Sumber: Data Pribadi, 2019 
Pada sirkulasi pengunjung, karyawan, dan service dibedakan sehingga tidak saling mengganggu. Pada pengunjung terdapat 4 titik masuk yaitu dari drop off bus yang dikhususkan untuk rombongan, drop off kendaraan pribadi yang dikhususkan untuk pengunjung yang membawa kendaraan beroda, halte untuk pemberhentian kereta dan bus yang di sediakan dari TMII, dan taman penghubung yang di hubungkan dengan tempat wisata apotik hidup dan dikhususkan untuk pejalan kaki.

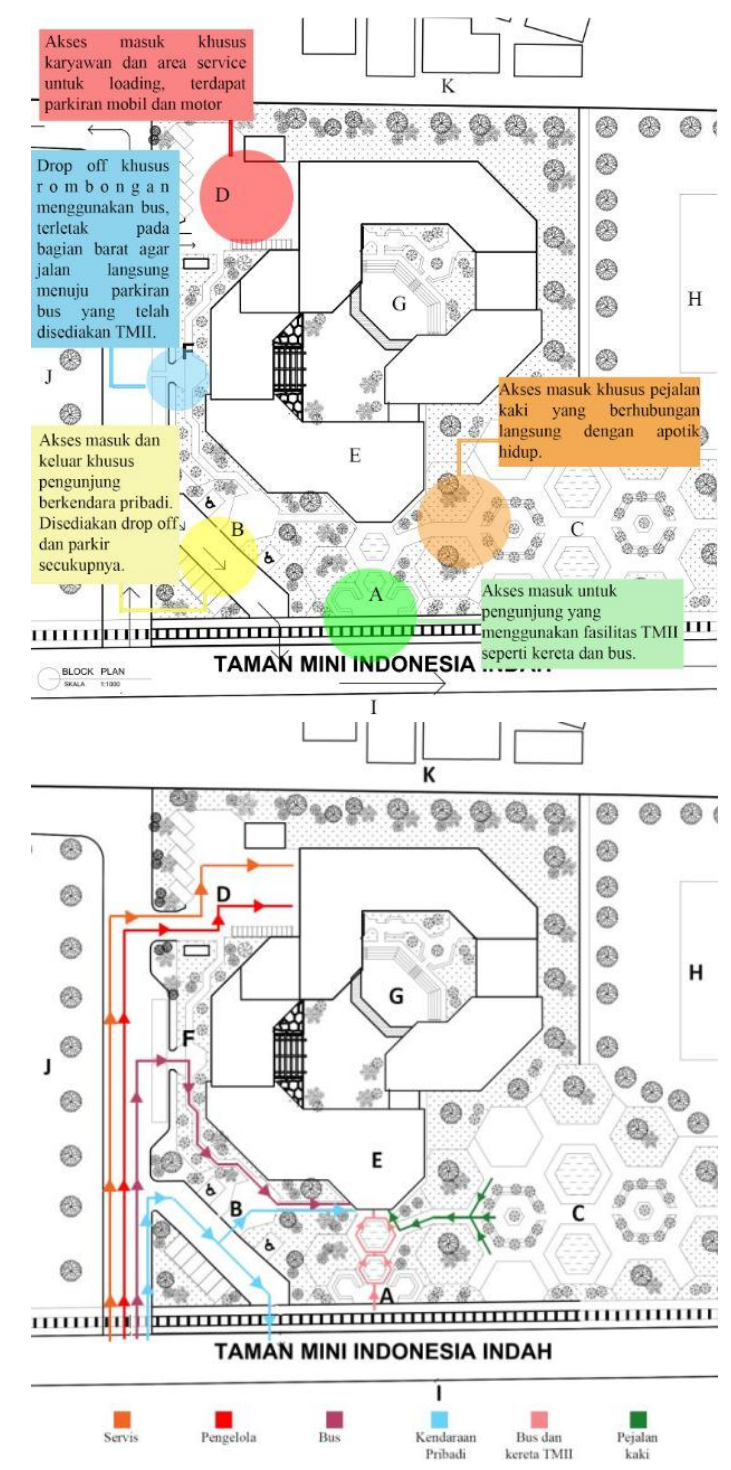

Gambar 9. Pencapaian Pengunjung Sumber: Data Pribadi, 2019

Pada bagian service dan pengelola diletakkan pada bagian yang sama karena untuk mudah dalam proses pengontrollan oleh karyawan dan tidak mengganggu area pengunjung. Penzoningan dibagi menjadi 7 bagian yaitu zona penerima (ruang lobby, ticketing), zona permainan tradisional, zona permainan modern, zona pengelola, zona retail : restoran, café, da toko souvernir, zona outdoor (area permainan tradisional outdoor, taman, amphitheater), zona service (loading dock, gudang, GWT, STP, ruang AHU, lift, ruang CCTV) 


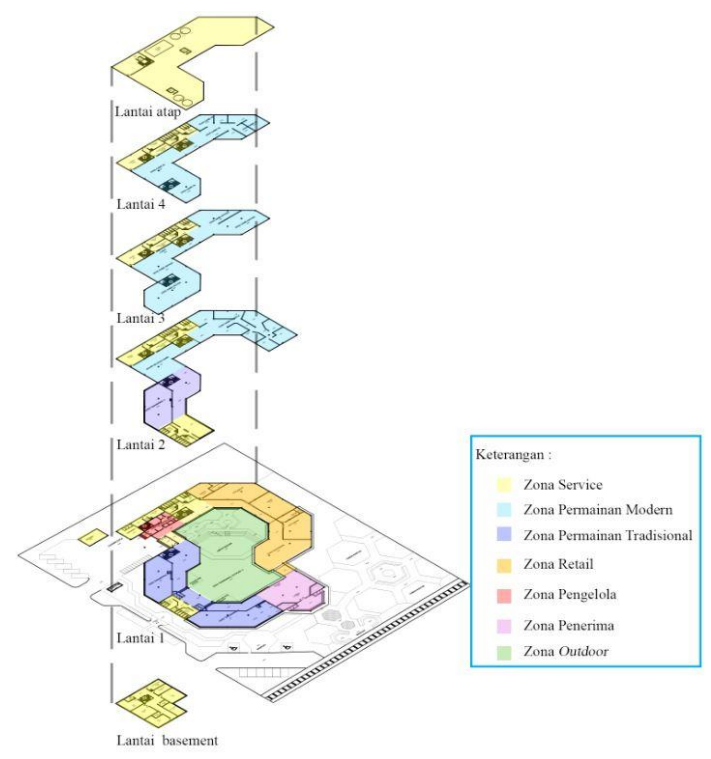

Gambar 10. Zoning per Lantai Sumber: Data Pribadi, 2019

Pada perancangan ruangan permainan pada permainan tradisional memiliki 4 zona permainan yang dibagi menurut permainannya. Dan dalam permainan modern dibagi menjadi 3 zona permainan. Yang pertama permainan game console, lalu permianan game arcade, dan terakhir permainan game $V R$. Pada permainan modern desain ruangan lebih mengarah ke pada hi-tec sehingga ruangan lebih tertutup sedikitnya dibuat bukaan pada bagian modern.

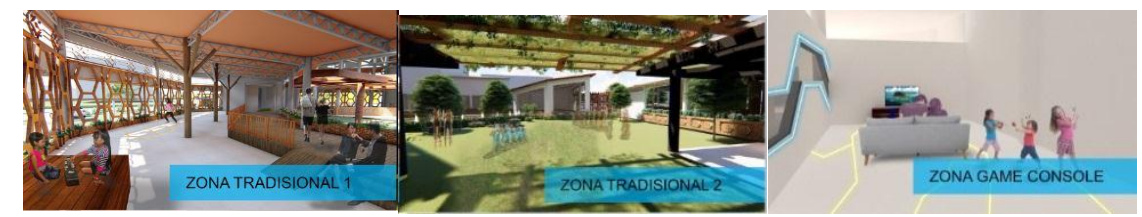

Gambar 11. Perspektif Interior Sumber: Data Pribadi, 2019

Pada bagian tampilan bangunan terbentuk antara kombinasi tradisional dan modern yang di mana di bedakan dari bahan / material fasad. Pada bagian tradisional lebih menggunakan material atau warna yang natural karena permainan tradisional dimainkan di alam. Pada bagian modern menggunakan bahan yang hi-tec seperti LED dan bahan ACP. Tetapi pada pola bentuk fasad tetap berbentuk sama yaitu hexagon agar etap terlihat satu massa. 


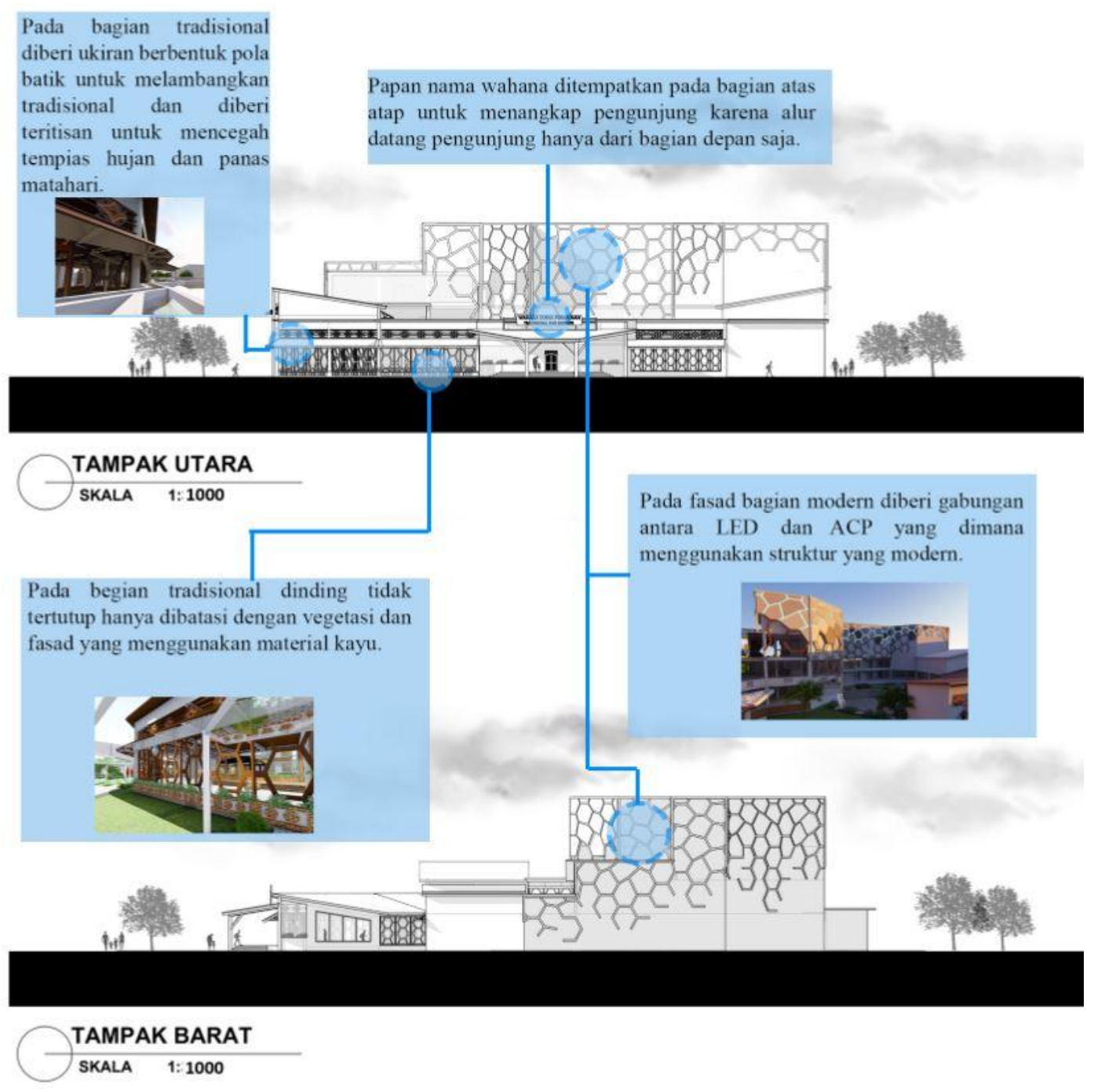

Gambar 12. Tampak

Sumber: Data Pribadi, 2019

Struktur utama bangunan adalah stuktur baja. Bagian kolom diberi pelapis penutu kolom untuk memberi kesan ekstetika. Struktur atap menggunakan dua struktur, pada bagian permainan tradisional menggunakan struktur baja dan pada yang modern menggunakan struktur beton dikarenakan untuk dijadikan area servis. Pada lantai bagian modern menggunakan raised floor setinggi $20 \mathrm{~cm}$ yang dimana dapat berfungsi untuk menutupi kabelkabel dari mesin permainan sehingga pengunjung tidak terganggu dan lantai bebas dari kabel. Pada beberapa bagian lantai menggunakan lantai sensorik dan LED untuk membuat bagian itu terasa beda dan lebih kearah hi-tec. Pada bagian modern tertututp maka sistem pencahayaan bangunan menggunakan pencahayaan buatan sedangkan tradisional dapat memakai pencahayaan alami tetapi tetap ditambahkan pencahayaan buatan.

Sistem pengudaraan pada bagian modern menggunakan AC central. Dan pada bagian modern menggunakan pengudaraan alami. Untuk system keamanan bangunan ini menggunakan media kamera CCTV yang jaringan pengawasannya dilakukan terpusat di ruang control pada lantai basement. Dan penempatan petugas pada tiap area permainan. Dan memiliki sitem ticketing untuk memasuki wahana. Ruang - ruang utilitas diletakkan pada lantai 1 dan pada lantai atas biasanya diletakkan tertutup dari pengunjung. Seperti pada kebutuhan air bersih yang dimana terdapat reservoir air bawah yang terletak pada lantai basement dan reservoir air atas yang diletakkan pada lantai atap. Sehingga penyaluran air pada bangunan menggunakan system down-feed. 


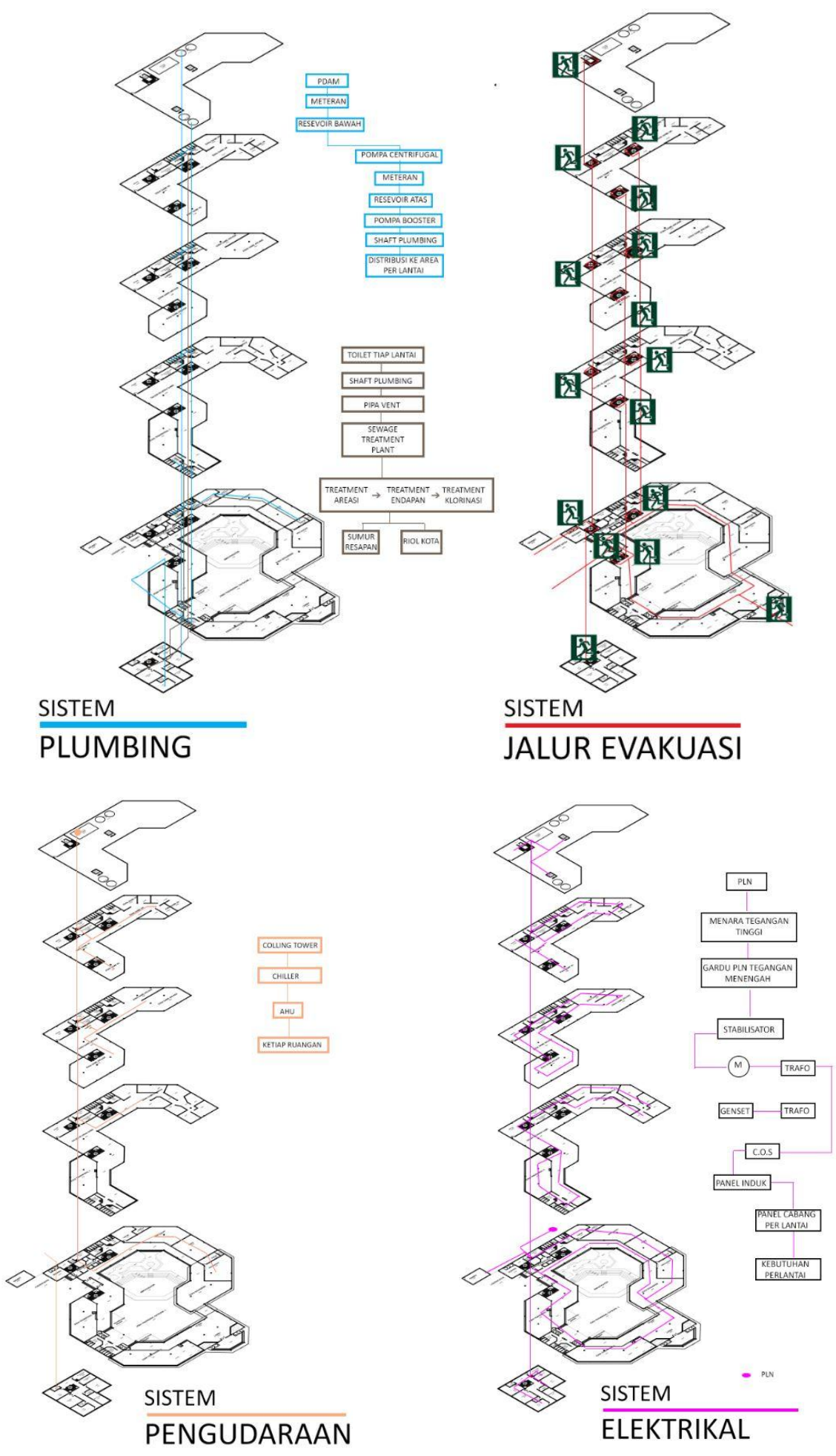

Gambar 13. Sistem Utilitas

Sumber: Data Pribadi, 2019

\section{KESIMPULAN DAN SARAN}

Kota Jakarta merupakan kota metropolis dan merupakan induk kota dari negara Indonesia. Pada kota Jakarta memiliki penduduk yang padat dari sini dapat dilihat dampaknya yaitu tingkat kemacetan yang tinggi, aktivitas yang padat, dan keberagaman kebudayaan penduduk. Dari sini maka timbullah beberapa hal perasaan negatif yang dialami penduduk seperti stress, 
penat, maupun jenuh. Salah satu hal yang dapat melepaskan perasaan tersebut adalah dengan mengunjungi tempat wisata. Tempat wisata di Jakarta sudah terbilang banyak, tetapi tempat wisata yang bersifat permainan sedikit dan hanya bagian kecil dari beberapa program lainnya.

Permainan adalah kegiatan yang paling bayak dilakukan orang-orang untuk menghibur diri. Permainan sudah ada sejak jaman dahulu. Permainan tradisional merupakan permainan yang jaman dahulu dimainkan anak-anak. Karena menggunakan material dari alam sekitar dan dimainkan secara bersama-sama. Tetapi pada jaman ini permainan tradisional sudah mulai jarang keliatan dan diketahui oleh generasi muda. Dan permainan modern yang sekarang sudah berkembang di seluruh negara lebih dikenal oleh kalangan generasi muda tetapi kurang dikenal oleh generasi tua. Maka dengan itu menyatukan permainan tradisional dan modern dalam satu tempat bisa menjadi sarana bermain, berlajar, dan bernostalgia.

Bangunan ini terbangun di Taman Mini Indonesia Indah yang dimana merupakan tempat wisata yang bertemakan budaya Indonesia. Sehingga cocok untuk tempat memperkenalkan dan memainkan permainan tradisional dan modern. Dan dalam proses pembentukan perancangan mengambil dari filosofi nilai-nilai dari tiap permainan baik dari tradisional dan modern dijadikan satu.

\section{REFERENSI}

Alife. (2015). Pengertian Turism, diunduh 7 Juli 2018, <www.alifeduca.blogspot.com/2015/06/pengertian-pariwisata-tourism.html>

AM, Titis Rum Kuntari. (2014). Museum Permainan Tradisional di Yogyakarta, diunduh 13 Juli 2018, < http://e-journal.uajy.ac.id/6805/3/TA213639.pdf>

Khoiri, Agniya. (2018). Permainan Tradisional, Puncak dari Segala Kebudayaan, diunduh 25 Agustus 2018, <https://www.cnnindonesia.com/hiburan/20180817120306-241-

323001/permainan-tradisional-puncak-dari-segala-kebudayaan>

Lai, Richard. (2017). This Japanese VR acade pt me inside 'Mario Kart', diunduh 13 Juli 2018, <https://www.engadget.com/2017/07/18/vr-zone-shinjuku-project-i-can-tour/>

Moore, Rowan. (2017). The Bilbao Effect : How Frank Gehry's Guggenheim Started A Global Craze, diunduh 1 Juli 2018, <https://www.theguardian.com/artanddesign/2017/oct/01/bilbao-effect-frank-gehryguggenheim-global-craze>

Museum, Direktorat. (1998). Permainan Tradisional Indonesia. Jakarta : Departemen Pendidikan dan Kebudayaan, Direktorat Jenderal kebudayaan, Direktorat Permuseuman.

Otaku, Hendy. Perkembangan console ame dan jenis game, diunduh 13 Juli 2018, <www.hendyotaku.weebly.com/macam-macam-console-dan-jenis-jenis-gamenya.html>

Specht, Jan. (2014). Architectural Tourism: Building for Urban Travel Destinations. Germany : Spinger Gabler. 